\title{
Correction to: Nation and gender in The eclipse of the crescent moon
}

\section{Ágnes Györke ${ }^{1}$}

Published online: 19 January 2022

(C) Akadémiai Kiadó, Budapest, Hungary 2022

\section{Correction to: Neohelicon XXXII (2005) 1, 129-136 https://doi.org/10.1007/s11059-005-0014-y}

The original article was erroneously published presenting symbols and special characters in place of the author name. The author name has been corrected and is presented correctly in this correction which supports the corrected article.

Additionally, this correction stands to correct the abstract. Text in the abstract shows the same error. The correct abstract text is as follows:

In this paper I read Géza Gárdonyi's novel, The Eclipse of the Crescent Moon, as a narrative of the Hungarian nation. After surveying the reception of the novel in the past century, pointing out the difficulties Hungarian literary criticism was facing when dealing with The Eclipse, I proceed to read the novel itself as a text that depicts an "imagined community" of Hungarians. I argue that while the Hungarian Self is imagined as an innocent child in the novel, the Turkish Other becomes depicted as a cunning animal dominated by primary instincts. I read The Eclipse as the story of expulsion from Paradise, invaded by the Turkish snake, focusing on the different paths the novel's main characters, Gergely and Éva, take, with the aim of analysing the feminine and masculine aspects of the nation imagined by the novel through their diverging stories.

The original article has been corrected.

Publisher's Note Springer Nature remains neutral with regard to jurisdictional claims in published maps and institutional affiliations.

The original article can be found online at https://doi.org/10.1007/s11059-005-0014-y.

Ágnes Györke

gyagnes@dragon.unideb.hu

1 Institute for English and American Studies, University of Debrecen, H-4010 Debrecen, Pf 73,

Hungary 